\title{
Stereotypes and the Unpaid Debt in the Episode of Rachel and Vidas in Cantar de Mio Cid
}

Este estudio aborda el polémico episodio de las arcas de arena en el Cantar de Mio Cid. La transacción usuraria entre Mio Cid y los judíos prestamistas Rachel y Vidas ha llevado a los críticos a interpretar la escena de diversas maneras. En este artículo, analizo evidencia textual anteriormente ignorada para argüir que ni Mio Cid ni Martín Antolínez pensaban cumplir con la promesa contractual de pagar a los prestamistas. Al contrario, ellos perciben la transacción como un engaño del cual obtienen una "ganancia". Mio Cid y Martín Antolínez se sienten con derecho de timar a los judíos debido a las tendencias antijudías prevalentes durante el tiempo de la composición del Cantar.

Palabras clave: Arcas de arena, Rachel y Vidas, usura, Cantar de Mio Cid, préstamo

This study addresses the controversial "arcas-de-arena" episode in the Cantar de Mio Cid. The usurious transaction between Mio Cid and the Jewish moneylenders Rachel and Vidas has led critics to interpret this scene in sundry ways. In this article, I provide overlooked textual evidence to argue that neither Mio Cid nor Martín Antolínez intends to honor the promise of repaying the moneylenders. Instead, they perceive the transaction as a deception from which they obtain a profit ("ganancia"). Mio Cid and Martín Antolínez feel entitled to cheat the Jews due to ever-increasing anti-Jewish sentiments prevalent during the time of the Cantar's composition.

Keywords: Sepharad, Arcas de arena, Rachel and Vidas, usury, Cantar de Mio Cid, moneylending

To my lovely children, Adrián, Nerea, and Sebastián

The episode of the arcas de arena is one of the most outstanding points of contention in Cantar de Mio Cid (ca. I207) scholarship, partly because determining whether or not Mio Cid repays his debt to the Jewish moneylenders has a direct bearing on the hero's moral standing. The author, 
a keen observer of human psychology and an accomplished artist, cloaks the characters' intentions with a veil of ambiguity, making it difficult for critics to find common ground. The episode's vagueness has generated a scholarly controversy that can be broadly divided into two categories: those who believe Mio Cid never repays his debt to the Jews, and those who assert he does. Alberto Montaner takes a more neutral stand, pointing out that the poet simply never returns to the issue (I47). Yet, even before Montaner, Ramón Menéndez Pidal had made a similar assessment to argue that the author has either forgotten or has had no time to recount an alleged redress that has taken place behind the scenes, as it were ("Poesía e historia" II9). Both of Menéndez Pidal's arguments are problematic, not only because they are rooted in the slippery grounds of hypothesis, but also because they suggest the poet's lack of concern for his Jewish characters. The aesthetic representation of Rachel and Vidas, indeed, exhibits some of the stereotypical hallmarks that identify them as "Jews" without explicitly saying that they are Jewish. ${ }^{.}$The purpose of this study is to contribute to the understanding of the role that Rachel and Vidas play in the dramatic fabric of the Cantar in order to determine whether or not the poet intended for Mio Cid to honor his contractual obligation with the Jews. To better comprehend the hero's intentions, this study follows a two-pronged line of inquiry: I examine anti-Jewish discourses and symbols that converge in the episode to portray the moneylenders as dehumanized characters who are deservedly deprived of their money, and I also look into previously unexamined semantic nuances in the dialogue that ensues between Mio Cid and Martín Antolínez after they have completed the transaction with the moneylenders.

Cidian scholars - myself included - who posit that Mio Cid did not reimburse the loan base their opinions largely on anti-Jewish undercurrents that inform the discursive tone and content of the episode (Bello 2IO-II; Spitzer I08-09; Smith 523-25; McGrady 52I-24; Rutherford 76I). These critics have offered abundant data to support their arguments, but they have overlooked more decisive information that helps readers determine not only textual evidence, but also intention. From Andrés Bello (I88I) to Alfonso Boix Jovaní (2006, 20I2), scholars have been asking (and answering) the wrong question, limited in breadth and depth: "did Mio Cid repay the loan?" (Smith 1965; McGrady 1985; Boix Jovaní 2006). Scholarly opinions differ as to whether or not Rodrigo made proper redress, when the poem, in fact, implies that he did not. Because verifiable evidence and dramatic events lay bare that the debt was never repaid, this study goes beyond this question, instead considering the following: why did the poet never intend for Mio Cid to repay the loan? This broader question, as opposed to the one 
debated in most studies - which could be answered with a simple yes or no - allows the reader to find deeper levels of meaning in the arcas de arena episode, Mio Cid's dramatic persona, and the Cantar as a whole.

The chronicle of Mio Cid's heroic life and deeds is one of the most riveting, inspiring, and popular ones in medieval Iberian literature. It is a story about a humbled warrior who achieves greatness and power against all odds thanks to his military prowess, humility, and Christian values. His extraordinary achievements, however, begin with his ability to overcome the precarious circumstances precipitated by courtly intrigues that result in an undeserved exile. After King Alfonso VI banishes Mio Cid for an alleged fiscal fraud, Rodrigo is powerless and bankrupt. He devises a plan to borrow money from Rachel and Vidas - two Jews from the Burgos Jewry. To stage the deception, he fills two chests with sand and seals them with golden nails to give the optical illusion of being filled with gold. Mio Cid, then, sends Martín Antolínez to negotiate with the Jews, who agree to lend him six hundred marcos. In turn, Rodrigo commits to leaving the two chests of gold - gold that turns out to be fake - in Rachel and Vidas's care until he is able to return the capital with an undisclosed, but presumably generous, interest rate. Shortly after securing the marcos, Antolínez reunites with Mio Cid, and during this brief scene, the poet offers an insight into Mio Cid's real intentions regarding the monetary transaction that has just taken place. More than four years later, the poet reintroduces Rachel and Vidas to the audience in a pathetic scene in which they beg Álvar Fáñez, Mio Cid's most trusted warrior, to intercede on their behalf so that Rodrigo, who has acquired great wealth and power, would reimburse the money. They are so desperate to recover their principal that they are willing to forgo any accrued interest. After this scene, the audience never hears from the Jews again, but the hero goes on to conquer many Moorish fortresses and cities, including Valencia, a victory which turned him into the most celebrated warrior of his lifetime and a trusted subject of King Alfonso.

PROCESSES OF STEREOTYPING RACHEL AND VIDAS

Just after Mio Cid maps out the ardid de las arcas de arena and communicates his plan to Martín Antolínez, the Cid-poet shifts the audience's attention from Rodrigo to the moneylenders. In an act of poetic intrusion, the author offers his audience access to a private space where he depicts Rachel and Vidas with the stereotypical image of the covetous Jew counting money, a chrematistic aberration poetically designed to convey a typological image of greed. The poet introduces Rachel and Vidas as embodiments of usury whose activities are "based solely on a stereotype" (Mirrer 79). The minstrel does not represent two men, but an action that 
helps define them as Jews without explicitly stating their ethnic identity. The emphasis on their act of counting money is designed to prompt the audience to perceive them as incarnations of greed and cupidity in detriment to their marks of humanity, which offers a stark contrast with the poet's introduction of Mio Cid, underscoring his human sensibility and individuality in the very first verse of the extant poem ("de los sos ojos tan fuertemientre llorando" v. I). ${ }^{2}$ The intrusion of Antolínez into their private, if not intimate, space is so abrupt that they have to pause momentarily from savoring the pleasure of the physical contact with the gold: "Rachel e Vidas en uno estavan amos, / en cuenta de sus averes, de los que avién ganados" (vv. IOO-OI). The moneylenders are symbolically stripped of their humanity and shown as "descarnadas categorías," "muñecos de trapo," and "falta de humanidad" (Diz 453). The poet presents them as two people fused into one, a type of bicephalous monster that simultaneously consumes and is consumed by money. The very act of counting money produces this merging of selves. John K. Walsh has remarked that the poet portrays his Jewish characters "'en cuenta de sus averes' as if this were their perpetual exercise" (Io). Rachel and Vidas, indeed, are portrayed as transactional machines programmed only to count money mechanically, an image of usury meant to stress their Jewishness. This notion is conjured in the second verse. The moneylenders are counting their wealth, but on a symbolic level, they are computing other people's averes. The past participle verb "ganados" indicates that the Jews are tallying the usurious product of their wealth, which they have earned ("ganados") by transgressing Christian tenets against moneylending, an economic activity dominated by Jews during the composition of the Cantar that the Church and the Christian laity deeply resented.

Martín Antolínez breaks the spell induced by their physical proximity to gold, and he succeeds in getting the Jews' full attention only because he brings with him the promise of increasing their heap of treasure. As part of his stratagem to deceive the moneylenders, Antolínez reaffirms (or confirms) Mio Cid's culpability, upholding as truth the false allegation of his accusers. Antolínez's misleading report, which the Jews are not requesting, shows his ingenuity, but also suggests a mens rea that portends to the greater deceit.3 After asking the moneylenders to swear that they will keep their agreement secret, he explains the situation in which Mio Cid finds himself as a result of the ira regia:

El Campeador por las parias fue entrado, grandes averes priso e mucho sobejanos; retovo d'ellos cuanto que fue algo, por én vino a aquesto por que fue acusado. 
Tiene dos arcas llenas de oro esmerado,

ya lo vedes, que el rey le á airado. (vv. Io9-I4)

Antolínez, the poet, the audience, and the reader know that this is a lie because Mio Cid had just lamented his enemies' fabricated accusation, while confessing to Antolínez that he was bankrupt and in desperate need to sustain himself and his warriors: "espeso é el oro e toda la plata, / bien lo vedes que yo no trayo nada, / e huebos me serié pora toda mi compaña" (vv. 8I-83). But Antolínez uses the royal indictment of fiscal fraud as a recourse to frame the deceit. Joaquín Casalduero, who believes that Mio Cid never intended to repay the loan, posits that Rodrigo is intentionally withholding the payment as means of punishing the moneylenders for believing in his guilt.4 Mio Cid's alleged knowledge of the Jews' misjudgment is hardly a justification for defrauding them. If all characters who believed in Mio Cid's culpability deserved punishment, King Alfonso would be the first to blame not only because he believes, but also because he acts upon his conviction that the Campeador is guilty.

Both the contemporaneous audience and the contemporary reader can charge the Jews with misjudging Mio Cid's innocence from a vantage point that neither Rachel nor Vidas has. Julio Rodríguez Puértolas calls attention to a problem that arches over the entire controversy of the arcas deception: some critics want to treat Mio Cid as (or even turn him into) a santo laico (I42; López Estrada 167; Sola-Solé 4). If Mio Cid were an eleventh-century secular saint, ironically, his action against the Jews would not only be justified, but also lauded because Christians perceived Jews - more so than Muslims - as the enemies of Christianity, as King Alfonso X el Sabio avers in a cantiga that has clear parallels with the Cidian arcas-de-arena episode. 5 Colin Smith has drawn a clear distinction between contemporary and medieval moral compasses: "[H]owever difficult it may be for us to accept it with our modern ideas of morality and our modern guilts about antiSemitism, the Cid's ability to cheat Jews was (in the mind of the author and of his twelfth-century audience) just another facet of his heroic character" (528). Leo Spitzer made a similar assessment with regards to medieval lax ideas or, to use a modern psychological term, desensitization to antiSemitism (I09-IO). Portraying and interpreting Mio Cid as a saintly personage, far from doing justice to the poet's artistic craft, does the author a disservice because it robs Rodrigo's poetic character of dramatic depth by divesting him of some of the very traits that render him "human" in all his complexity. ${ }^{6}$

In light of the ira regia and the "stolen" arcas, the moneylenders understand Mio Cid's predicament. The Castilian hero needs liquidity to launch his military campaign against the Moors, and he is willing to pawn 
the chests of gold until he can safely recover them. It is not that greed blinds the moneylenders. Their deal with Mio Cid is merely another transaction of the many they likely undertake on a daily basis. Because the risk and amount involved are higher than their average petty loans to impoverished Christians, they expect a higher revenue. Rachel and Vidas, then, are delighted by the possibility of earning more money in one transaction. Rather than being blinded by avarice, their decision to invest in Mio Cid is rational. Despite believing that Rodrigo has defrauded the king - or perhaps because they believe he has - they are willing to assume the risk of lending their money, knowing that if Mio Cid defaults, the chests of gold secure their investment:

Nós huebos avemos en todo de ganar algo;

bien lo sabemos, que él gañó algo

cuando a tierra de moros entró, que grant aver ha sacado.

Non duerme sin sospecha qui aver trae monedado.

Estas arcas prendámoslas amos,

en logar las metamos que non sea ventado. (vv. 123-28, emphasis added)

The poet depicts this interaction as secretive, and by doing so, it gives the impression of foul intent, even though their words lack malice or deceit.7 Although they speak in private, Rachel and Vidas are not devising a plan to con Mio Cid, but simply deliberating whether or not this deal is lucrative. When the Jews express that they have the need to "ganar algo," they refer to the interests of the loan, which is within the purview of moneylending. During this private interaction, the Jews concede that they believe in Mio Cid's guilt, which suggests that they do not perceive the Campeador as a righteous and upright person, thus foreshadowing their own downfall.

As deft businessmen, Rachel and Vidas are assertive and forthright when asking for their investment and their interest. The Jews are eager to enter into the deal, trying to charge the highest rate Mio Cid is willing to pay, for they want to help the hero, but also make a profit. Hence, in one simple question, Rachel and Vidas convey the core of their concerns regarding the transaction: "mas dezidnos del Cid, ¿de qué será pagado / o qué ganancia nos dará por todo aqueste año?" (vv. 129-30). Much like the poet blends Rachel and Vidas into one, the Jews interlace two questions into one. Antolínez answers the first question. Rodrigo needs six hundred marcos to fund his military campaign, but he never answers the second part of the question. Antolínez indicates that Mio Cid is willing to pay any interest rate the moneylenders impose upon him ("Mio Cid querrá lo que sea aguisado" v. 132), which has a direct bearing on Donald McGrady's hypothesis that Antolínez does not weigh the money because he never thinks of repaying 
the debt. In this case, Antolínez is willing to commit to the highest interest rate because he never considered returning the money. Mio Cid reiterates his eagerness to grant any rate the Jews foist on him, giving them his word that he will repay their loan handsomely. ${ }^{8}$ Trusting that the hero will reward their act of faith, Rachel and Vidas do not quibble over details. Just like Mio $\mathrm{Cid}$, the Jews enter into the contract without knowing the exact interest rate, confident that the deal will be lucrative because, as the Crónica particular, which narrates the life and deeds of Mio Cid, suggests, the Jews place their unconditional trust in Mio Cid's word and good intentions. ${ }^{9}$

Even if some of the details of the transaction are unspecified, both parties agree to its terms and conditions. ${ }^{10}$ The final agreement reads as follows: the moneylenders loan Mio Cid six hundred marcos, and they keep the chests of gold as collateral. If the Jews open the chests before the period of one year, they forfeit the accrued interest. The legalistic jargon pervading the entire covenant attests to its solemnity:

Martín Antolínez el pleito á parado

que sobre aquellas arcas darle ien seiscientos marcos,

e bien ge las guardarién fasta cabo del año,

ca assíll' dieran la fe e ge lo avién jurado,

que si antes las catassen, que fuessen perjurados,

non les diesse mio Cid de la ganancia un dinero malo. (vv. I60-65, emphasis added)

Mio Cid and Antolínez take the necessary measures to cover their deceit, threatening legal actions if the terms of the agreement are violated. This scene, which plays out like a formal court document, has multiple purposes. The poet likely employs it as a humorous device, "exploiting the stereotype by supplying a 'humorous' example of two greedy usurers who fall prey to a Christian's hoax" (Mirrer 69; McGrady 522-23). Antolínez's facetious act of making them swear as if he were a judge on a promise as worthless as the content of the arcas would have made the contemporaneous audience laugh and cheer, ridiculing the credulity of the Jews, while extoling Antolínez's sly witticism. But on a more pragmatic level, the binding contract serves the purpose of keeping the moneylenders from discovering the ruse before Mio Cid departs from Burgos with their money. The scene is a parody of a solemn covenant between two parties that serves the practical purpose of concealing the actual content locked within the chests. With a stroke of a pen, the poet has turned two "money-hungry" Jews into typological objects of social satire, deprived of any traces of humanity. And it is through this culturally violent process that the author justifies the use of and abuse against Rachel and Vidas, conceding that the Christian hero perceived the loan as spoils of war (ganancia) rather than a contractual obligation. ${ }^{\text {II }}$ 
MIO CID PERCEIVES THE LOAN AS GANANCIA

The term ganancia - also employed by the Jews when asking about the interest rate - which the poet uses throughout the poem to signify "profit" or "earnings," is key to understanding Mio Cid and Antolínez's intentions with regards to the loan. In his analysis of the arcas episode, McGrady notes that the Campeador does not intend to repay the loan, reminding us that Antolínez never weighs the marcos, and taking a loan without the proper weighing was traditionally understood as indicative of lack of intention to make a redress $\left(523^{-27}\right)$. When the Jews and Antolínez come to an agreement (vv. I60-65), the term ganancia is used to mean "interest" or simply "revenue." All the excess money of the principal becomes the profit of the investment. In the episode of the "arcas" alone, the poet uses the verb "ganar" and its derivatives seven times, and after every conquest of Mio Cid, the term reappears multiple times without varying in meaning. This semantic consistency is significant because both Mio Cid and his henchman characterize the loan and the ensuing "commission" of thirty marcos as ganancia. In this section, I will show that the use of the term "ganancia" to refer to the loaned principal amounts to an admission that the author never intended for Mio Cid to return the money, let alone the accrued interest.

Let us recall that after both parties complete the transaction, Antolínez asks the moneylenders for his commission: "ya don Rachel e Vidas, en vuestras manos son las arcas; / yo que esto vos gané bien merecía calças" (vv. I89-90, emphasis added). Antolínez refers to the interest rate as a profit (vos gane). The irony is that since he knows the deal is a scam, far from helping them earn money, Antolínez is divesting them of their possession. In his study of the arcas episode, Nicasio Salvador Miguel calls attention to the customary tradition of offering a small gift to someone who facilitated a lucrative deal (199-200). Montaner adds, in relation to the traditional calzas, "esta prenda o su equivalente en dinero [era] un regalo frecuente en la época en concepto de comisión o gratificación por haber mediado en un negocio" (74). In this case, Antolínez proposes that he has enabled the Jews to earn a profit from the business with Mio Cid. Gratefully (and voluntarily), the Jews give the henchman thirty marcos. Whereas Antolínez is right in considering these thirty marcos as income (ganancia) for his mediation, Mio Cid's six hundred marcos represent a loan, but that is not how Mio Cid and Antolínez perceive the money.

When Antolínez returns to Mio Cid's tent, which is set up just outside of the confines of Burgos, he rejoices in his negotiating prowess, but most important of all, he preens about the money he has been able to secure. Mio Cid receives him with promises to repay his services, and the loyal vassal 
boasts about the double deceit: "vengo, Campeador, con todo buen recabdo; / vós seiscientos e yo treinta he ganados" (vv. 206-07, emphasis added).12 Antolínez feels neither regret nor guilt for deceiving the moneylenders. On the contrary, he is overjoyed by his act of deception, confessing that they have grossed a combined amount of six hundred and thirty marcos. Mio Cid has the opportunity to correct Antolínez's assertion, but instead, he accepts his assessment as if it had been part of the original plan. The poet resorts to this zeugmatic construction to underscore that both the thirty and the six hundred marcos are considered a profit (ganancia), like all the loot earned in his battles against the Moors - a parallel that Colin Smith underscores in his analysis of the arcas episode.13 One could make the case that there is an implied verb modifying "vós seiscientos," as in "vós [conseguiste or recibiste] seiscientos," but it is textually unwarranted. The poet consistently employs the zeugma elsewhere in the poem.14 Rather than being a discursive ellipsis, Mio Cid and Antolínez's joviality suggests that the henchman means what he says, and his sardonic words belie Miguel Garci-Gómez's hypothesis that Antolínez truly considers Rachel and Vidas his "amigos caros" ("Don Rachel" 2II-I2). In an act of poetic irony, Mio Cid commits the same fraud against the Jews for which he has been accused and exiled by King Alfonso. After more than four years - some one thousand lines later - the poet reintroduces the bankrupt Rachel and Vidas to demand their capital. They exhibit a distraught despondency ("a los pies le caen" v. I43I) because they sense Mio Cid's unwillingness to honor his word (Vv. I432-38). As noted above, some critics adduce this reappearance to argue that the loan is (or will be) repaid. ${ }^{15}$ My interpretation is that their reintroduction only proves that, at least nearly five years after the accord, the money has not been returned, which simply confirms Antolínez's assertion that the six hundred marcos were seen as a profit. Despite Álvar Fáñez's non-binding assurance that he would convey their message to Mio Cid, Rodrigo has taken the Jews' money as ganancia. Fáñez's friendly reminder would only be effective if Mio Cid had genuinely forgotten about his debt and had the intention of repaying, which based on his utter disregard for his legal obligation, he does not. He never displays any intention to return the money.

The arcas episode is relevant to assess Mio Cid's personality because the poet reveals a level of duplicity that suggests his ability, if not willingness, to deceive the Jews. When planning the deceit, Mio Cid is portrayed as a reluctant participant of the trick: "yo más non puedo e amidos lo fago" (v. 95). In other words, Rodrigo is not to blame for his action because his misfortunes have driven him to condescend to commit the offence. This notion, however, contradicts Mio Cid's picaresque trick performed against Rachel when the Jew asks the hero for a piece of Arabic 
fabric, "una piel vermeja, morisca e ondrada, / ... en don que la yo aya" (vv. 178-79). Garci-Gómez adduces Rachel's request to argue that Rachel is a Christian woman (El Burgos 75), an ingenious, albeit textually unwarranted, hypothesis that would eliminate the polemical element of anti-Judaism altogether. ${ }^{16}$ Mio Cid responds with comical, yet unbecoming, duplicity that rivals Antolínez's picaresque act of asking for a commission: "plazme, dixo el Cid, d'aquí sea mandada, / si vos la aduxier d'allá, si non, contalda sobre las arcas" (vv. I8o-8I, emphasis added). Mio Cid knows that Rachel cannot draw the money from the chests to purchase the Moorish cloth because they contain sand. At the narratological level, the poet makes Mio Cid utter this wordplay for humorous effect, underscoring the uncanny naïveté of the Jews who are doubly tricked. When Antolínez asks for a commission, his deceit takes away from his integrity as a knightly warrior, but readers accept his trickery because, compared to Mio Cid's epic stature, Antolínez is a minor character. Mio Cid's insensitive joke violates both moral codes of conduct and the poetic rules that govern the "generic appropriateness," which demands "kings... [to] act like kings, slaves like slaves" (Morgan 228). In this rare instance, the poet makes Rodrigo act like a trickster rather than an epic hero. It is hardly a coincidence that the poet directs this trickery against Jews, as it conveys the Christian animus against Jews prevalent during the composition of the Cantar.

REPRESENTATION OF JEWISH STEREOTYPES

Modern scholars, particularly those who perceive Mio Cid as a national icon and a paradigm of integrity rather than an artistic creation within a superb work of art, find Rodrigo's action hard to reconcile with his otherwise impeccable morality. These critics fail to view the poet's representation of Rodrigo's interaction with the Jews as driven by an ever-increasing antiJewish resentment during the twelfth and thirteenth centuries, namely, well over a century after Mio Cid's death. Hence, the anti-Jewish sentiment deployed in the Cantar reflects not Rodrigo's (or even Antolínez's) feelings or dealings with Jews or Moors, but those of the poet. The arcas-de-arena episode, which has no bearing on Rodrigo's historical biography, reflects this shifting attitude towards Jews in thirteenth-century Iberia. In his study on the Burgos Jewry, Francisco Cantera painstakingly describes the dynamic relationship between Burgalese Christians and Jews from the reign of King Alfonso VI (IO77-IIO9) through their expulsion from Spain in I492. Cantera notes that the Jews of Burgos enjoyed periods of ethnic and religious tolerance as well as financial prosperity, but they also suffered from racial tensions and economic abuse. Facing mounting pressure from ecclesiastical authorities and local communities, King Fernando III (ca. II99- 
1252) adopted a harsher stance against the Burgos Jewry, forcing its residents to wear distinctive clothes that identified them as Jews, while threatening to "suspender toda clase de comunicación con los judíos" who refused to abide by the royal edict (Cantera 62). The enforcement of sartorial difference, which was first legislated in the Fourth Council of the Lateran in 1215, suggests not only the institutionalization of anti-Judaism but also a statement of Jewish inferiority. This social unrest, as can be surmised, was rooted in the Christians' perception that Jews imposed "inmoderatas usuras" upon Christians, while refusing to pay the tithe to the Church (Cantera 63). This anti-Jewish ferment, which also predominates in Berceo's Milagros de Nuestra Señora and Alfonso X's Cantigas de Santa Maria, is the undertow in the aesthetic representation of Rachel and Vidas's characters. ${ }^{17}$

The paradigmatic image of usury with which the author introduces Rachel and Vidas is steeped in anti-Jewish prejudices. For a medieval author, portraying a character as a usurer was tantamount to drawing a picture of a Jew and, therefore, a demonic Other in the mind of his audience. Edna Aizenberg has called attention to the equivalences that medieval Iberians drew to help form the collective Jewish identity: "the usurer = Jew was an integral part of this satanic picture" (479). Seymour Resnick also observes the implicit association between usury and the aesthetic representation of Rachel and Vidas in the Cantar (54). In the Spanish Middle Ages, moneylending was a complex phenomenon that was supported and protected by royal authority because monarchs relied on Jewish loans for their protracted wars against Iberian Muslims, but it was also deeply resented by members of the noble elite, Church officials, and common people (Chazan 98). Whereas King Alfonso would endorse Rachel and Vidas's moneylending - perhaps not their loan to Mio Cid, given that he has issued an edict prohibiting anyone from offering aid and comfort to the exiled hero - the minstrel and his audience would deeply resent their usurious business. Nicasio Miguel reminds us that Jews monopolized "el préstamo usurario" in the twelfth and thirteenth centuries. In response, the text of the Laws of Cuenca (legislated ca. II89-90) dedicates a subsection of Title XIII solely to Jewish usury, which attests to the inextricable association between Jews and usury: "la identificación del judío con el prestamista o usurero cundió en seguida...; y la literatura, en fin, se hizo eco también del asunto" (206). The characters of Rachel and Vidas attest to Nicasio Miguel's assertion, as their main function within the dramatic fabric of the Cantar is to underpin the sense of Christian identity by contrast, stressing the Jewishness of the usurers.

As noted above, the poet does not explicitly identify Rachel and Vidas as Jews, but leads his audience to discover their Jewishness by means of a 
contrived portrait based on stereotypical descriptions: "Raquel and Vidas have the unpleasant characteristics associated in the medieval Christian mind with Jewish usurers" (Resnick 54). The poet uses other cognitive techniques to predispose his Christian listener against the Jews. These literary conceits serve the function of bringing mental images that underscore the deep divide between the victim "us" and the victimizer "Other" in the minds of the audience. In the remainder of this study, I analyze three examples of this kind of cultural violence against Jews that may help the reader understand the anti-Jewish undercurrents at play during the episode of the arcas de arena. First, we analyze the symbolism of the thirty marcos that Antolínez "earns" from the transaction. Second, we look into the function of the thirty marcos as a symbol of Judas's betrayal of Christ, while tracing the connection between the names of Judas-Vidas. Lastly, we conclude with the stereotypical imagery embedded in Doña Ximena's prayer before her husband's departure from Castile following his exile.

None of these examples amount to brazen or violent acts of antiSemitism in the same way that some of Berceo's or Alfonso X's Marian miracles exhort Christian worshipers to kill or steal from Jews, but they do offer a glimpse into the resentment and mistrust that twelfth- and thirteenth-century Iberians had vis-à-vis Jews. The parallel between Antolínez's thirty marcos and Judas's thirty silver coins received for the betrayal of Christ as articulated in Matthew 26.15 seems relatively straightforward. Resnick insinuates the connection with a rhetorical question, but without offering his own assessment: "did the poet choose the figure thirty because of its unpleasant association with the betrayal of Christ, attributed to the Jews?" (54). After Resnick's suggestive observation, no other scholar has commented on the link between both quantities and their far-reaching semiotic possibilities, despite the symbolic connection between Judas and the thirty pieces of silver that medieval people could easily trace. The association of the figure "thirty" as symbol of Judas's betrayal and a constitutive part of Jewish identity, to be sure, was widely attested in literary accounts.

In De bello judaico, Josephus narrates then-prince Titus's siege and destruction of Jerusalem in 70 AD. After capturing the city, the Roman prince sells thirty Jews for one denarius in retribution for having sold Christ for thirty denari. The legendary story La destrucción de Jerusalem, which survives in Castilian and Catalan manuscripts, in King Alfonso's General estoria, and in Juan Manuel's Libro de los estados, either recasts or refers to this folktale to stress the wickedness of Jews. This demonization of Jews had real life consequences, as it likely inspired the murder of as many as thirty Jews who were falsely accused of killing a single Christian boy in Hungary 
in $1529 .{ }^{18}$ Peter Dronke, furthermore, calls attention to a thirteenth-century poem in which Christ gives Judas thirty coins of silver to buy food in Jerusalem $(67-68)$. From a hermeneutic standpoint, Jesus is foreshadowing Judas's betrayal, but from a cultural viewpoint, the poet establishes a clear link between the traitor and the amount (thirty) for which he sells Christ. There is yet another example closer to Rachel and Vidas's context. Cantera notes that in I240, King Fernando III imposed upon the Burgos Jewry an annual tithe of "treinta dineros a la iglesia catedral burgalesa" (64). As contemporary readers, it is difficult to assess how royal authorities and poets arrived at the amount of thirty, but it is undeniable that the evocation of the quantity bears a symbolic value linked to Judas's betrayal that would have a strong cultural resonance in the Christian laity and medieval audiences. The digit "thirty" helps define Judas's identity. It functions as a metonymy for his treasonous act that the author of the Cantar artistically exploits to heighten the dramatic effect of his poem.

In the Cantar, Vidas symbolically replaces the biblical Judas as traitor, but their roles are inverted: Judas received thirty coins for selling God's son, and Rachel and Vidas (Judas) return the thirty coins earned from selling God's commodity, i.e., time. Throughout the Christian Middle Ages, as Jacques Le Goff notes, people perceived usury as a sin against God because the usurer was a thief who stole from God. The scholastic theologian Peter Lombard (ca. I096-II60) asserts: "the usurer sells nothing to the borrower that belongs to him. He sells only time, which belongs to God. He cannot, therefore, make a profit from selling someone else's property" (Le Goff 39). In the Middle Ages, Le Goff reminds us, usurers were charged with selling days and nights (40-4I). This act of selling time is also evoked in the Cantar. When Rachel and Vidas ask Antolínez how much money Mio Cid needs and how much interest he is willing to pay, the moneylenders make it clear that they are charging interest for the chronological duration of the loan: "¿qué ganancia nos dará por todo aqueste año" (v. I30). In the Jews' direct question, they posit that their ganancia will stem from units of time rather than from the amount of money borrowed. Judas, then, is charged with selling God's son, and Raquel and Vidas with selling God's commodity (time) to His (Christian) sons.

The poet stresses the connection between the Jews' usurious dealings and Judas's betrayal. Salvador Miguel asserts that the amount of thirty marcos for a mere commission is too high. Antolínez asks for a pair of shoes ("calças") for his mediation, thus acting as a double agent, since he is also serving and being rewarded by Mio Cid. Instead of a low-cost pair of shoes - or its equivalent - the poet makes the moneylenders give him thirty marcos - an exorbitant five percent commission from the principal of six 
hundred (Salvador Miguel 202). It is revealing that the Cid-poet divides the loan into two amounts: three hundred marcos of gold and three hundred marcos of silver. Both quantities are factors of thirty. Is the poet making the Jews (Judas) pay twentyfold the amount of the betrayal? The thirty-marcos commission is not only excessive, but also runs counter to the stereotype of the miserly Jew. The purpose of this act of munificence is not to represent Jews as generous since the main objective of the arcas episode is to amuse the Christian audience by recounting the deception against usurious Jews. On the contrary, the amount of thirty marcos serves the purpose of making the cognitive association between the Jews and Judas, whose name may have been the poet's intended name for Vidas.

Cidian scholars nearly unanimously accept that the etymology of Vidas's name derives from the Hebrew "Hayyim," which translates literally into Castilian as "vidas" (Salvador Miguel I89; Mirrer 7I). The name "Vidas" was a common name in medieval Castilian Jewries. Some critics have adduced the Hebrew origin of their names to show that the moneylenders are Jews. Some critics have alternatively suggested that Vidas's name derives from a scribal misreading. Ángel de los Ríos y Ríos was the first scholar to posit that Vidas's original name could have been Judas: "y del aprovechado israelita, 'Judas' [i.e. Vidas], escrito probablemente en el original 'Iudas', con el punto de la jota un poco adelantado, copió 'Vidas', que no es nombre judío" (59i). De los Ríos y Ríos does not have the contemporary scholarship at hand to help him issue a more informed assessment. In his interpretation, however, Vidas becomes the abuser (aprovechado) and his name has emerged as a misreading of "Iudas."

Since de los Ríos y Ríos, other critics have associated Vidas's name with Judas. María Eugenia Lacarra notes that the Cid-poet resorts to stereotypical names as a pejorative mechanism. For Lacarra, the poet names non-noble characters with "un nombre casi genérico, estereotipado y utilizado con intensión peyorativa, como ocurre con los judíos Raquel y Vidas (posiblemente Iudas [40])." Garci-Gómez goes further in his assessment, asserting in the analysis of the etymology of the Jews' names that when we read "Vidas," it should be understood as "Judas" (El Burgos II). This interchangeable identity Vidas-Iudas would be less relevant, were it not for the thirty marcos that he gives to Antolínez/Mio Cid. The poet brings to mind Judas's betrayal, and associates Judas with the characters Rachel and Vidas. It is hard to know if a less-informed twelfth- or thirteenth-century audience would have picked up on these cues, but the minstrel's performative gestures and body language could have been used to guide a medieval audience to arrive at these conclusions. This onomastic witticism may also serve as a joke to insinuate a Dantesque "contrapasso" avant la 
lettre in which the Christ-selling Judas (Vidas) returns the thirty coins to the Christ-like hero (Mio Cid).

The shadow of Judas reappears once again in a different context. The recontextualization does not mean that it is unrelated. As Aizenberg notes, all these signifiers "Jew $=$ deicide $=$ Judas $=$ usurer $=$ Satan came together" (480). This time the poet refers to Jews as a "race" in order to place upon them the onus of Jesus's crucifixion. The association of Jews with the dogma of Christ's crucifixion, derived from long-established exegeses, occurs in Doña Ximena's prayer. Casalduero has identified Doña Ximena's prayer as a part of the literary genre of the "oración narrativa." As Casalduero notes, these literary prayers are generally composed of three sections: I) an invocation, 2) a narration of a series of miracles, and 3) a petition ("Sobre la 'oración"' II3-I4). The allusion to anti-Jewish stereotypes in oraciones narrativas always occurs in the recast of the miracles performed by Christ. Juan Ruiz's Libro de Buen Amor alludes to similar anti-Jewish discourses in his "oración narrativa": "Señor Dios, que a los judíos, pueblo de perdiçión" (v. 3a). Before begging God to safeguard her husband, Doña Ximena reminds Christ that He "a los judíos te dexeste prender; do dizen monte Calvarie / pusiéronte en cruz" (vv.347-48). Doña Ximena hastens to implicate the Jews in the imprisonment of Christ without mentioning the Romans who, in effect, had the legal authority to apprehend and crucify felons. Doña Ximena's rashness to blame Jews is also conveyed grammatically. The enjambment shows her alacrity to get to the first hemistich of the next verse, in which she charges Jews with Christ's passion and death. Enjambment is an infrequent rhetorical recourse in the Cantar, which renders Doña Ximena's hastiness more noteworthy.

Let us recall, moreover, the role Judas plays in Christ's imprisonment and crucifixion. Contrary to other medieval accounts, Doña Ximena does not name Judas, but rather the entire Jewish community. Her intent is not to implicate one person but an entire ethnic group as means of actualizing and misplacing the blame. Hence it is not just Judas - or even just those Jews who were present during Christ's passion - who betrayed Christ, but the category "Jews." Doña Ximena's prayer is relevant also because this is the only instance in the Cantar in which the term "judíos" appears in the text, and it surfaces to paint the Jews as callous deicides "whom the Christians and the Catholic Church of the time saw as the unrepentant murderers of Christ" (Pavlović 378). This narrative of the Jews as Christ's killers, Lazar Moshe notes, derives from fourth-century theologians who felt the necessity to create a guide for the "teaching of contempt" by articulating a series of myths, among them "the myth of Jewish diaspora as God's punishment of the Jews for the crucifixion; the myth of the Jews as Christ's killers" (40). 
Doña Ximena's prayer underscores the dogma of Christ's crucifixion and the role Judas/Jews played in it.

In the mindset of medieval Christendom, the killing of Christ became an integral part of the collective identity of Jews. This kind of teleological determinism frames Jews as being predisposed to deicidium, an ideology that Berceo's milagro I8 openly embraces and perpetuates. During Late Antiquity and the Middle Ages, theologians preached that every Jew "was born with a stain of inherited guilt for the crucifixion of the Christian saviour, and the late medieval church in Spain had even employed a system of certificates of 'purity of blood"' (De Lange 23). Marta Ana Diz observes that in Spanish medieval literature, "la figura del moro recibe siempre mejor tratamiento que la del judío" because "con su presencia recuerda constantemente la muerte del dios cristiano" (452). Throughout the Middle Ages, the doctrine of Christ's crucifixion was "an ever popular theme to arouse hostility toward the Jews" (Resnick 55). In his Partida VII, Título XXIV, Ley I, King Alfonso X posits that Church leaders, emperors, and kings have only accepted Jews in their kingdoms "porque ellos viviessen en cativerio para siempre, et fuesse remembranza a los omes quellos vienen del linaje de aquellos que cruçificaron a Nuestro Señor Jesucristo" (qtd. in Aizenberg 479). In other words, Jews served as a foundational bedrock in the fashioning of a Castilian Christian identity. In most Western Kingdoms, Jews represented a welcome enemy that would, as Rosemary Ruether points out, constitute "an intrinsic need of Christian self-affirmation" (qtd. in De Lange 27). Alfonso X's candid concession regarding the institutionalization of antiJudaism in Pan-European kingdoms suggests that Mio Cid's act of embezzlement is not perceived as a moral flaw. On the contrary, since Jews are perpetually bloodstained with Christ's death, their punishment is not only merited, but also encouraged. Doña Ximena's imputation helps us understand the negative views Christians held of Jews and Jewish symbols. Given the even-growing anti-Jewish sentiments in twelfth- and thirteenthcentury Castile, it is reasonable to believe that the poet of the Cantar stages the deceit of the arcas as a symbolic retribution for the Jews' perceived wickedness, representing Mio Cid as a character in need who knows that Rachel and Vidas's (Judas's) loan is not a loan but, as Martín Antolínez conceded, a ganancia.

The episode of the arcas de arena, therefore, culminates the process of stereotyping, a mimetic reflection of the social ferment caused by the usurious business of Iberian Jews. The poet's lack of concern for his Jewish characters suggests his own resentment against the Jewish moneylending class, but it also reflects the anti-Jewish discourses rampant during the time of the composition of the Cantar (Pavlović 378-82). The poet never 
entertains the idea of Mio Cid repaying his debt because to him - and his contemporaneous audience - Jews incarnated all the traits of usurious thieves that deserved to be cheated. People who stole from Jews would have been perceived as worthy of praise, as Spitzer and Smith noted, rather than blame. It is not that the poet simply forgets to narrate an alleged redress of the debt, as Menéndez Pidal, Boix Jovaní and others have argued. If the poet had intended for Mio Cid to repay his debt, he would have addressed it during the Jew's second appearance, or he would have staged a brief scene afterwards. After all, he narrates with painstaking detail Mio Cid's lavish gifts sent to the King Alfonso and the monastery of Cardeña. Instead, the emphasis on the term ganancia referring to the loan, coupled with the antiJewish undertones deployed in strategic sections of the poem, reveal that a lack of repayment was a part of the original design of the Cantar. The poet deftly, yet subtly, portrays the Jews as the "Other," an "out-group" (Aizenberg 483) that preys on impoverished Christians by means of usurious loans. For the poet, therefore, the six-hundred-marcos ganancia that Mio Cid retrieves from the Jews represents but a small sum for the sinful usury that Jews impose upon God-fearing and God-loving Christians.

Vanderbilt University

NOTES

I Menéndez Pidal was the first critic to posit that Rachel and Vidas were Jewish based on their Semitic names ("Introducción," Poema de mio Cid 33-37). Salvador Miguel, who denies the notion that Vidas's name stems from the misreading of "Iudas," bolsters Menéndez Pidal's interpretation: "Rachel y Vidas... solo pueden ser judíos dadas las actividades a que se consagran" (204).

2 All quotes from the Cantar come from Alberto Montaner's edition. From now on, I give the verse number in the body of the text. For a thorough analysis on how the emphasis on Mio Cid's eyes and powerful gaze render him fully human and worthy of empathy, see Luis F. López González (2018).

3 Even Boix Jovaní, who has written multiple articles arguing that Mio Cid has paid his debt in full, has a Freudian slip, admitting that the entire transaction is a fraud and a deceit: "la ausencia de lo militar en el fraude de las arcas de arena" and later avers that Mio Cid is "obligado a actuar como un estafador" ("La primera victoria" 367-68).

4 See Casalduero: "Si el Cid no paga a Rachel y Vidas no es por avaricia o mezquindad, es porque no quiere; no devuelve el dinero para dar una lección moral a estos dos hombres viles que han creído que el Cid podía haberse 
quedado con las parias" ("El Cid echado" 44); also Boix Jovaní ("El Cid pagó" 77).

5 Alfonso X's "Cantiga" 348 narrates a story in which the Virgin Mary directs a king - perhaps Alfonso X himself - to the place where some Jews have a hidden treasure. The theft is endorsed by the institution of the Crown and counselled by Virgin Mary. Just as the poet of the Cantar, Alfonso X and Mary justify the act with a double excuse. First, the treasure will help fund the continued war against the Andalusian Muslims, which is also the reason the Campeador embezzles the Jews. Second, the narrator of the cantiga labels Jews as the enemy of Christians, an enemy worse than Moors: 'dos judeos, seus ẽemigos, a que quer peor ca mouros" (v. 48).

6 Even medieval audiences were aware of the humanity of epic heroes. Américo Castro notes that medievals did not expect epic heroes to be morally perfect, but human beings with virtues and flaws: "la ejemplaridad del héroe épico era un entretejido de virtudes y de pecados, de religión y de mundanidad" (134).

7 Casalduero believes the Jews are ill-disposed, and asserts that they want to deceive Mio Cid: "su astucia torcida y de mala fe resalta sobre la astucia de buena calidad del Cid" ("El Cid echado" 43). But his assertion is derived from interpreting purported intentions from the Jews and not from the poet's words.

8 After a brief greeting, Mio Cid turns to reminding them of his exile, and he promises them that they will always be well off as long as he lives: "Ya me exco de tierra, ca del rey só airado; / a lo que·m’ semeja, de lo mio avredes algo, / mientras que vivades non seredes menguados" (156-58).

9 Bandera Gómez notes the opinion of the author of the Crónica, but he argues that the Cid-poet steers clear from this attitude, shifting the blame of the swindle to the Jews: "los judíos caen en la trampa que les tiende su misma malicia. No es que los judíos se fíen del Cid, sino todo lo contrario; caen en la trampa porque sólo juzgan las apariencias y desconfían de la intachable conducta del Campeador. He aquí sus palabras, que nos darán la clave del episodio: 'non duerme sin sospecha qui aver trae monedado'” (II9). And he adds: "el Cid los hace caer en las redes de su propio engaño, de su falta de fe" (I24). Aizenberg notes the flawed premise Bandera Gómez relies on to analyze the interaction between the Jews and Mio Cid: "Bandera Gómez... sees the Raquel and Vidas episode precisely as a replay of the struggle between Christ and Satan...: the Cid is to Christ as Raquel and Vidas are to the Devil" (48I).

IO It is important to point out that this agreement is not a mere promise promises are not legally binding - but an obliging contract between two parties that had far-reaching consequences if the debtor defaults. If Rachel and Vidas do not refer their case to the proper authorities, we might hypothesize, it 
is because they are aware of the royal edict which prohibited everyone from providing aid and comfort to the exiled Cid.

II Boix Jovaní has interpreted Mio Cid's act of deception as his first successful battle in the military career of the hero, comparing the stolen money to the spoils of war that take place in the ensuing battles in his way to Valencia ("La primera victoria" $363-68$ ).

I2 In his study of humor in the Cantar, John Rutherford intuitively quotes these words to argue that Mio Cid never thinks of repaying the debt. On the one hand, Rutherford reminds us of McGrady's observation that Antolínez's disinterest to weigh the marcos, which the Jews see as a sign of goodwill and trust, indicates that he does not intend to repay. On the other hand, Rutherford links these verses to the second appearance of the Jews, which introduces another funny episode to humiliate the moneylenders (760).

I3 Smith contends that Mio Cid "no more thinks of paying them than he does of restoring the sword Colada and other booty to Ramón Berenguer; both were won in fair fight, the loan by a battle of wits and bluff, the sword by skill on the field" (528).

I4 See, for example, Mio Cid's accusation of cowardice to the Count of Carrión during the Cortes of Toledo: "quando pris a Cabra e a vos por la barba" (v. 3288) in which the verb "pris" describes the double act of winning the town of Cabra and grabbing the count's beard.

I5 Menéndez Pidal, for example, defends the idea that Mio Cid repays the loan adducing the Jews' encounter with Álvar Fáñez: "para opinar en contra me fundo en que no basta leer la escena del engaño, pues mucho más adelante, cuando los judíos se quejan a Álvar Fáñez del fraude, el poeta anuncia que el Cid pagará largamente el pasajero engaño (v. I436). Después de este anuncio, poco importa que el poeta no se acuerde más de decirnos cómo el Cid recompense a los judíos" ("Poesía e historia" II9).

I6 Garci-Gómez's hypothesis, however, has been widely refuted, even by those who deny any traces of anti-Semitism in the Cantar.

I7 In his study about the representation of Jews in Alfonso X's Cantigas, Albert I. Bagby offers five categories into which all Jews in the Cantigas fall: "(I) the Jew as an archenemy of Christianity; (2) the Jew as the devil's disciple; (3) the Jew as a symbol of avarice; (4) the Jew as a traitor; and (5) the Jew as a Christian convert" (675).

I8 In his study on usury in Shakespeare's The Merchant of Venice, James A. Arieti recounts the gruesome story: "thirty Jews confessed under torture to the crime and were burned in public" (2OI). When the child was found alive, it was discovered that Count Wolf of Bazin had abducted the child and levelled an accusation against the Jews to escape his Jewish creditors. 
WORKS CITED

A IZ E n B ER G, E DNA. "Raquel y Vidas: Myth, Stereotype, Humor." Hispania 63.3

(I980): 478-86.

A L F ONSO X, E L SA B I o. Cantigas de Santa Maria. Vol. III, ed. Walter Mettmann.

Madrid: Castalia, 1986.

arieti, James A. "Magical Thinking in Medieval Anti-Semitism: Usury and the

Blood Libel." Mediterranean Studies 24.2 (2016): 193-218.

BA GBy, ALBert i JR. "The Jew in the Cántigas of Alfonso X, El Sabio." Speculum 46.4

(I971): $670-88$.

Bandera gó mez, ce sá re o. "El Poema de Mío Cid": Poesía, historia, mito. Madrid:

Gredos, I969.

B L L O, An D Rés. Notas a la Gesta de Mio Cid. In Obras completas II. Santiago de

Chile: Pedro G. Ramírez, I88I.

Bo IX jovaní, Alfonso. "El Cid pagó a los judíos." La Corónica 35.I (2006): 67-8I.

—. "Promesas y juramentos en el Cantar de Mio Cid." Bulletin of Hispanic Studies

89.I (2OI2): I-I3.

—. "La primera victoria del Campeador en el Cantar de Mio Cid." Revista de

Literatura Medieval 26 (2014): 363-68.

CANTERA, FRAN Cis Co. "La judería de Burgos." Sefarad I2 (I952): 59-IO4.

CASA L d e Ro, Jo A quí . . "El Cid echado de tierra." Estudios de literatura española.

Madrid: Gredos, 1962. 28-58.

—. "Sobre la 'oración narrativa' medieval: estructura, origen, supervivencia." Anales de la U de Murcia 16 (1957-1958): 113-25.

CA St r o, A mér I co. España en su historia: Cristianos, moros y judíos. Barcelona:

Crítica, I983.

CHAZAN, Rов R T. The Jews of Medieval Western Christendom Iooo-I5oo.

Cambridge: Cambridge UP, 2006.

DE LANGE, NiCholas. "The Origins of Anti-Semitism: Ancient Evidence and

Modern Interpretations." Anti-Semitism in Times of Crisis. Eds. Sander L.

Gilman and Steven T. Katz. New York: New York UP, 1991. 21-37.

DE LoS Ríos y Ríos, ÁngEL. "Exactitud histórica y geográfica del Poema del Cid."

Revista de España 14 (I879): 588-99.

DiZ, mARTA ANA. "Raquel y Vidas: la guerra en la paz o el 'art' del desterrado."

Romance Quarterly 35.4 (I988): 449-55.

DRONKE, PETER. The Medieval Lyric. London: Hutchinson, 1978.

GA RC I-Gó ME Z, M I G UE L. "Don Rachel e Vidas, amigos caros.” RFE 56 (I973): 209-28.

-. El Burgos de Mío Cid: temas socio-económicos y escolásticos, con revisión del

antisemitismo. Burgos: Imprenta Diputacional Provincial, 1982. 
H о о K, DA VID. Review of El Burgos de Mio Cid. Temas socio-económicosy escolásticos, con revisión del antisemitismo, Miguel Garci-Gómez. Romance Philology 39. 4 (1986): 526-30.

huerta, eleazar. Poética del Mio Cid. Albacete: Gráficas Panadero, I990.

lacarra, marí a eugen i A. "Introducción." Poema de Mio Cid. Madrid: Taurus, I982. LAZAR, moshe. "The Lamb and the Scapegoat: The Dehumanization of the Jews in Medieval Propaganda Imagery." Anti-Semitism in Times of Crisis. Eds. Sander L. Gilman and Steven T. Katz. New York: New York UP, I99I, 38-80.

LE GOFF, JACQUES. Your Money or your Life: Economy and Religion in the Middle Ages. New York: Zone Books, 1988.

Ló PE Z ESTRADA, FRANCISCo. Panorama crítico sobre el Poema del Cid. Madrid: Castalia, 1982.

Ló PEZ, GonZÁlez, Luis F. "Mio Cid's Powerful Gaze: The Subduing of the Lion in the Cantar de Mio Cid." Bulletin of Spanish Studies 95.6 (2018): 563-86.

M CGRADY, D o N A LD. "Did the Cid Repay the Jews? A Reconsideration." Romania io6 (I985): 518-27.

menéndez Pidal, RAmón, ed. Introducción. Poema de mio Cid. Madrid: La Lectura, I9I3. 7-II4.

—. "Poesía e historia en el Mio Cid. El problema de la épica española." Nueva Revista de Filología Hispánica 3.2 (1949): II3-29.

michael, ian, ed. Poema de Mio Cid. Madrid: Castalia, 1976.

M IRRER, L OU ISE. Women, Jews, and Muslims in the Texts of Reconquest Castile. Ann Arbor: The U of Michigan P, 1996.

montaner, ALBerto. Introducción. Cantar de Mio Cid. Barcelona: Crítica, 2007· $7^{-}$ 46.

Morgan, J. R. "The Episode of the Jews: An Aspect of the 'Historicity' of the Poema de Mio Cid in the Context of 'Political Correctness."' Historicism Essays on Hispano-Medieval Narrative. Eds. Barry Taylor and Geoffrey West. London: Maney Publishing for the Modern Humanities Research Association, 2005. 35985.

RESNICK, SEYMour. "The Jew as Portrayed in early Spanish Literature." Hispania 34.I (I95I): $54-58$.

rodríguez, PuÉrt ola s, Julio. "El Poema de Mio Cid: nueva épica y nueva propaganda." Mio Cid Studies. Ed. Alan D. Deyermond. London: Tamesis, I977. I4I-60.

RUIZ, JUAN. Libro de buen amor. Ed. Alberto Blecua. Madrid: Cátedra, 2008. rutherford, john. "The Comical and the Humorous in the Poema de Mio Cid." Bulletin of Spanish Studies 83.6 (2006): 739-69.

SALVAD OR MigUEL, NiCASio. "Reflexiones sobre el episodio de Rachel y Vidas en el Cantar de Mio Cid." Revista de Filología Española 59.I (1977): I83-224.

Smith, colin. "Did the Cid Repay the Jews?" Romania 86 (I965): 520-38. 
S O LA-SO LÉ, J OS E P M. "De nuevo sobre las arcas del Cid." Kentucky Romance Quarterly 23.I (1976): $3^{-15}$.

SPITZE R, LE 0. "Sobre el carácter histórico del Cantar de Mio Cid." Nueva Revista de Filología Hispánica 2.2 (1948): 105-17.

walsh, јон к. "Performance in the Poema de mio Cid." Romance Philology 44.I (I990): $\mathrm{I}^{-25}$. 